\title{
Perbandingan Faktor Atribut pada Toko Nol Limbah di Kota Surabaya: Pendekatan Semantic Differential
}

\author{
Annisa Deaneke Prabowo Putri, dan Berto Mulia Wibawa \\ Departemen Manajemen Bisnis, Institut Teknologi Sepuluh Nopember (ITS) \\ e-mail: berto@mb.its.ac.id
}

\begin{abstract}
Abstrak-Terdapat berbagai tantangan yang dihadapi bisnis dengan konsep ramah lingkungan, seperti dampak dari fenomena perubahan preferensi konsumen yang mempertimbangkan aspek ramah lingkungan pada konsumsinya. Tantangan tersebut yakni adanya fenomena greenwashing serta pertumbuhan jumlah kompetitor di pasar seiring waktu. Penelitan ini bertujuan untuk menganalisis perbandingan profil antara dua toko nol limbah yang terdapat di Kota Surabaya, yakni Alang-Alang Zero Waste Store dengan kompetitornya, yakni Mamaramah Eco Bulk Store. Desain penelitian yang digunakan adalah deskriptif. Pengumpulan data dilakukan menggunakan kuesioner online yang disebarkan kepada 22 sampel. Hasil penelitian menunjukkan bahwa kompetitor Alang-Alang Zero Waste Store, yakni Mamaramah Eco Bulk Store, lebih unggul dibandingkan Alang-Alang Zero Waste Store dengan mengungguli di 9 faktor atribut dari total 15 faktor atribut. Terdapat implikasi manajerial yang dapat dimplementasikan pihak Alang-Alang Zero Waste Store dengan tujuan mengoptimalkan faktor atribut produk dan toko yang dimiliki merek. Implikasi manajerial tersebut adalah menambahkan pilihan metode pembayaran, mengadakan event marketing serta in-store marketing, dan meningkatkan kualitas pelayanan yang diberikan oleh pramuniaga toko.
\end{abstract}

Kata Kunci-Toko Nol Limbah, Faktor Atribut Produk, Faktor Atribut Toko, Analisis Skala Pengukuran Semantic Differential

\section{PENDAHULUAN}

$Z^{\prime}$ ERO waste merupakan pendekatan seluruh sistem yang bertujuan untuk menghilangkan limbah dibandingkan mengelola limbah yang dihasilkan [1]. Konsep zero waste hadir di tengah perhatian akan aspek keberlanjutan yang terus mendapatkan momentum terutama di negara dengan populasi yang semakin bertambah dengan dampak buruk bagi lingkungan yang tinggi [2]. Hal ini dapat dilihat dari perubahan perilaku konsumen di mana 80 persen konsumen Asia Tenggara seperti Indonesia, yang bersedia membayar lebih untuk produk dan jasa yang peduli pada isu lingkungan dan sosial melebihi wilayah lain di seluruh dunia seperti Timur Tengah, Afrika, Amerika Latin, Eropa, dan Amerika Utara [3]. Selain itu, sebanyak 78 persen responden dari Indonesia bersedia membayar ekstra untuk produk atau jasa dari perusahaan yang memiliki komitmen untuk membawa dampak positif bagi sosial dan lingkungan [4]. Dapat dilihat bahwa kenaikan jumlah konsumen Indonesia yang sadar akan adanya isu lingkungan dan mulai melakukan perubahan preferensi pembelian ke produk ramah lingkungan cukup signifikan, yakni sebesar 14 persen dari tahun 2014 ke tahun 2015. Hal ini menunjukkan bahwa kini konsumen memiliki preferensi dan motivasi untuk lebih sadar lingkungan yang diwujudkan melalui penggunaan kekuatan dan suara mereka berdasarkan seberapa besar dampak yang diberikan produk yang mereka beli terhadap lingkungan. Penelitian ini dilakukan di Kota Surabaya sehingga walaupun data yang dilaporkan adalah konsumen Indonesia secara keseluruhan, namun Surabaya merupakan kota terbesar kedua di Indonesia berdasarkan jumlah penduduk, sehingga mampu merepresentasikan kondisi perubahan preferensi konsumen yang sedang terjadi.

Terdapat permasalahan yang disebabkan dari tren peningkatan data jumlah konsumen yang mempertimbangkan dampak lingkungan pada konsumsinya. Hal ini menyebabkan berbagai bisnis memanfaatkan perubahan perilaku ini. Alihalih menerapkan secara nyata nilai ramah lingkungan pada proses dan produknya, terdapat bisnis yang sekadar melabeli diri dengan citra ramah lingkungan tanpa benar-benar meminimalisasi dampak negatif bisnis pada lingkungan. Akibatnya, terdapat fenomena greenwashing yang terjadi karena adanya tumpang tindih antara praktek nyata bisnis dengan apa yang dikomunikasikan kepada konsumen [5]. Greenwashing adalah klaim lingkungan perusahaan yang tidak jujur, meragukan atau menyesatkan. Hal ini menimbulkan ketidakpercayaan konsumen terhadap komunikasi bisnis mengenai produk ramah lingkungan. Greenwashing mengurangi popularitas produk yang secara nyata ramah lingkungan dan mengurangi efektivitas green marketing.

Saat ini terdapat bisnis lokal di Surabaya yang telah mengusung konsep zero waste, yakni Alang-Alang Zero Waste Store. Selain menghadapi fenomena greenwashing, AlangAlang Zero Waste Store juga harus menghadapi kompetitor lain di Surabaya yakni Mamaramah Eco Bulk Store yang didirikan hanya setelah tiga bulan Alang-Alang hadir [6]. Hal ini dapat menjadi tantangan bagi Alang-Alang Zero Waste Store karena pelanggan dihadapkan oleh berbagai pilihan produk yang dapat dijangkau dengan mudah sehingga kemungkinan pelanggan berpindah ke lain merek menjadi lebih tinggi. Oleh karena itu, Alang-Alang Zero Waste Store perlu mengidentifikasi faktor atribut 
yangmenjadipertimbangan pelanggan dalam melakukan penilaian pada toko nol limbah.

\section{LANDASAN TEORI}

\section{A. Zero Waste Store}

Zero waste store merupakan bisnis yang mengusung konsep keberlanjutan dengan memberikan dampak negatif yang rendah bagi lingkungan [7]. Bisnis zero waste store membawa konsep keberlanjutan pada dua aspek yang menjadi perhatian konsumen saat ini, yakni kepedulian pada isu lingkungan, baik dari sisi produk yang ditawarkan ataupun pada bisnis yang dijalankan. Istilah zero waste dan upaya untuk mengganti barang sekali pakai dengan alternatif yang dapat didaur ulang serta ramah lingkungan pertama kali dimulai pada tahun 2011 [8]. Oleh karena itu, zero waste store merupakan konsep toko yang masih akan terus berkembang.

\section{B. Skala Pengukuran Semantic Differential}

Skala pengukuran semantic differential adalah skala peringkat 7 poin yang memiliki makna semantik yang dibatasi oleh dua atribut dengan sifat yang bipolar dengan hasil data digunakan untuk analisis profil. Penggunaan skala semantic differential pada penelitian ini dapat membantu menentukan perbedaan dan persamaan secara keseluruhan di anatara objek yang diteliti berdasarkan nilai mean [9].

\section{METODE PENELITIAN}

\section{A. Desain Penelitian}

Penelitian ini termasuk penelitian deskriptif sesuai dengan tujuan penelitian, yakni untuk mengidentifikasi penilaian pelanggan (pada Tabel 2) terkait faktor atribut toko (pada Tabel 1) dan produk Alang-Alang Zero Waste Store dan Mamaramah Eco Bulk Store. Data yang dibutuhkan adalah data primer mengenai penilaian responden mengenai faktor atribut kedua toko nol limbah (pada Tabel 3).

\section{B. Sampel}

Sampel penelitian diperoleh dari hasil data kuesioner yang disebarkan melalui Google Formulir kepada pelanggan pelanggan berumur 18-59 tahun yang pernah melakukan pembelian di kedua toko secara sekaligus, yakni Alang-Alang Zero Waste Store dan Mamaramah Eco Bulk Store pada 6 bulan terakhir. Pemilhan responden menggunakan metode purposive sampling yakni teknik penentuan sampel dengan pertimbangan tertentu dengan jumlah minimal sampel kurang dari dan sama dengan 30 responden [10]. Penelitian dengan teknik ini telah dilakukan oleh Ramadhani (2019).

\section{Metode Analisis Data}

Analisis data dilakukan dengan menggunakan analisis skala pengukuran semantic differental. Analisis skala semantic differential digunakan untuk menganalisis perbandingan profil antara Alang-Alang Zero Waste Store dengan Mamaramah Eco Bulk Store untuk mengetahui keunggulan dan kekurangan bisnis berdasarkan penilaian dari para pelanggannya. Analisis
Tabel 1.

Definisi Operasional Faktor Atribut

\begin{tabular}{|c|c|c|}
\hline No & Variabel & Definisi \\
\hline 1 & $\begin{array}{l}\text { Harga tidak sesuai } \\
\text { kualitas - Harga sesuai } \\
\text { kualitas }\end{array}$ & $\begin{array}{l}\text { Kemampuan toko untuk memberikan } \\
\text { harga yang sesuai dengan kualitas } \\
\text { produk yang dijual }\end{array}$ \\
\hline 2 & $\begin{array}{l}\text { Ketidaknyamanan saat } \\
\text { berbelanja - } \\
\text { Kenyamanan saat } \\
\text { berbelanja }\end{array}$ & $\begin{array}{l}\text { Kenyamanan secara keseluruhan } \\
\text { pelanggan saat berbelanja di toko }\end{array}$ \\
\hline 3 & $\begin{array}{l}\text { Jenis produk terbatas - } \\
\text { Jenis produk beragam }\end{array}$ & $\begin{array}{l}\text { Keberagaman dan kelengkapan } \\
\text { barang-barang yang dijual }\end{array}$ \\
\hline 4 & $\begin{array}{l}\text { Pelayanan } \\
\text { mengecewakan - } \\
\text { Pelayanan memuaskan }\end{array}$ & $\begin{array}{l}\text { Pelayanan secara keseluruhan seperti } \\
\text { pelayanan pramuniaga, keberadaan } \\
\text { pelayanan dalam bentuk self-service, } \\
\text { kemudahan mengembalikan barang } \\
\text { dan pelayanan siap antar }\end{array}$ \\
\hline 5 & $\begin{array}{l}\text { Fasilitas fisik seadanya - } \\
\text { Fasilitas fisik memadai }\end{array}$ & $\begin{array}{l}\text { Fasilitas seperti AC, toilet yang } \\
\text { nyaman, store layout meliputi } \\
\text { penempatan barang serta rak yang } \\
\text { rapi dan tersusun sesuai kategori, } \\
\text { lahan parkir dan pintu keluar yang } \\
\text { dekat, dan tempat pembayaran }\end{array}$ \\
\hline 6 & $\begin{array}{l}\text { Suasana tidak } \\
\text { menyenangkan - } \\
\text { Suasana menyenangkan }\end{array}$ & $\begin{array}{l}\text { Suasana pada toko meliputi } \\
\text { kebersihan, penerangan, aroma yang } \\
\text { menyegarkan dan menenangkan, } \\
\text { warna yang atraktif }\end{array}$ \\
\hline 7 & $\begin{array}{l}\text { Lokasi sulit dijangkau - } \\
\text { Lokasi strategis }\end{array}$ & $\begin{array}{l}\text { Lokasi yang strategis, mudah dicapai } \\
\text { pada lalu lintas yang tidak terlalu } \\
\text { padat dan dilewati oleh trasportasi } \\
\text { umum }\end{array}$ \\
\hline 8 & $\begin{array}{l}\text { Tidak dapat diandalkan } \\
\text { - Dapat diandalkan }\end{array}$ & $\begin{array}{l}\text { Persepsi konsumen ketika melihat } \\
\text { merek dengan menyatakan bahwa } \\
\text { merek tersebut kuat dan dapat } \\
\text { diandalkan }\end{array}$ \\
\hline 9 & $\begin{array}{l}\text { Produk tidak ramah } \\
\text { lingkungan - Produk } \\
\text { ramah lingkungan }\end{array}$ & $\begin{array}{l}\text { Dampak dari bahan yang digunakan } \\
\text { dalam produk dan kemasan }\end{array}$ \\
\hline 10 & $\begin{array}{l}\text { Proses tidak ramah } \\
\text { lingkungan - Proses } \\
\text { ramah lingkungan }\end{array}$ & $\begin{array}{l}\text { Dampak proses transformasi dari } \\
\text { bahan baku hingga menjadi produk } \\
\text { jadi }\end{array}$ \\
\hline 11 & $\begin{array}{l}\text { Penggunaan tidak ramah } \\
\text { lingkungan - } \\
\text { Penggunaan ramah } \\
\text { lingkungan }\end{array}$ & $\begin{array}{l}\text { Dampak lingkungan selama proses } \\
\text { pemakaian produk }\end{array}$ \\
\hline 12 & $\begin{array}{l}\text { Manajemen akhir tidak } \\
\text { ramah lingkungan - } \\
\text { Manajemen akhir ramah } \\
\text { lingkungan }\end{array}$ & $\begin{array}{l}\text { Kemungkinan penggunan kembali } \\
\text { dan daur ulang produk }\end{array}$ \\
\hline 13 & $\begin{array}{l}\text { Bahan baku bukan dari } \\
\text { produsen atau sumber } \\
\text { daya lokal - Bahan baku } \\
\text { dari produsen atau } \\
\text { sumber daya lokal }\end{array}$ & $\begin{array}{l}\text { Sumber bahan baku dari produsen } \\
\text { atau sumber daya lokal }\end{array}$ \\
\hline 14 & $\begin{array}{l}\text { Fungsionalitas rendah - } \\
\text { Fungsionalitas tinggi }\end{array}$ & $\begin{array}{l}\text { Tingkat kegunaan produk bagi } \\
\text { konsumen }\end{array}$ \\
\hline 15 & $\begin{array}{l}\text { Bahaya bagi kesehatan - } \\
\text { Aman bagi kesehatan }\end{array}$ & $\begin{array}{l}\text { Tingkat dampak kesehatan diri dari } \\
\text { produk dan penggunaan produk }\end{array}$ \\
\hline
\end{tabular}

profil didapatkan melalui hasil perhitungan dan perbandingan statistik dari nilai mean pada setiap skala atribut.

\section{Atribut Produk}

Faktor atribut ditentukan berdasarkan studi kepustakaan dari berbagai sumber mengenai faktor yang mendorong pelanggan untuk membangun hubungan berkelanjutan dengan toko nol limbah dengan mempertimbangkan atribut toko serta atribut produk. Penggunaan atribut toko digunakan karena atribut 
Tabel 2.

Kategori Penilaian Pelanggan

\begin{tabular}{llc}
\hline \hline Kategori Penilaian & Kategori Penilaian Pengguna & Rentang Nilai \\
\hline & Sangat mengecewakan & $1,00-1,86$ \\
& Mengecewakan & $1,89-2,72$ \\
Kualitas Pelayanan & Cukup mengecewakan & $2,73-3,58$ \\
(Mengecewakan- & Netral & $3,59-4,44$ \\
Memuaskan) & Cukup memuaskan & $4,45-5,30$ \\
& Memuaskan & $5,31-6,16$ \\
& Sangat memuaskan & $6,17-7,00$ \\
\hline \hline
\end{tabular}

Tabel 3.

Penilaian Faktor Atribut Toko Nol Limbah

\begin{tabular}{|c|c|c|c|c|c|}
\hline No & Faktor Atribut & A & Kategori & $\mathrm{M}$ & Kategori \\
\hline 1 & $\begin{array}{l}\text { Kesesuaian Harga } \\
\text { dengan Kualitas }\end{array}$ & $\begin{array}{c}5,7 \\
7\end{array}$ & $\begin{array}{l}\text { Sesuai dengan } \\
\text { Kualitas }\end{array}$ & $\begin{array}{c}5,6 \\
8\end{array}$ & $\begin{array}{l}\text { Sesuai dengan } \\
\text { Kualitas }\end{array}$ \\
\hline 2 & $\begin{array}{l}\text { Tingkat } \\
\text { Kenyamanan } \\
\text { Berbelanja }\end{array}$ & $\begin{array}{c}6,0 \\
5\end{array}$ & Nyaman & $\begin{array}{c}6,1 \\
4\end{array}$ & Nyaman \\
\hline 3 & $\begin{array}{l}\text { Tingkat } \\
\text { Keberagaman } \\
\text { Produk }\end{array}$ & $\begin{array}{c}6,0 \\
0\end{array}$ & Variatif & $\begin{array}{c}6,1 \\
4\end{array}$ & Variatif \\
\hline 4 & $\begin{array}{l}\text { Kualitas } \\
\text { Pelayanan }\end{array}$ & $\begin{array}{c}5,9 \\
1\end{array}$ & Memuaskan & $\begin{array}{c}6,2 \\
7\end{array}$ & $\begin{array}{l}\text { Sangat } \\
\text { Memuaskan }\end{array}$ \\
\hline 5 & $\begin{array}{l}\text { Kualitas Fasilitas } \\
\text { Fisik }\end{array}$ & $\begin{array}{c}6,1 \\
4\end{array}$ & Memadai & $\begin{array}{c}6,1 \\
8\end{array}$ & $\begin{array}{l}\text { Sangat } \\
\text { Memadai }\end{array}$ \\
\hline 6 & $\begin{array}{l}\text { Keadaan atau } \\
\text { Atmosfer Toko }\end{array}$ & $\begin{array}{c}5,7 \\
7\end{array}$ & $\begin{array}{l}\text { Menyenangka } \\
\mathrm{n}\end{array}$ & $\begin{array}{c}6,5 \\
0\end{array}$ & $\begin{array}{l}\text { Sangat } \\
\text { Menyenangkan }\end{array}$ \\
\hline 7 & Lokasi Toko & $\begin{array}{c}5,3 \\
6\end{array}$ & Strategis & $\begin{array}{c}5,5 \\
5\end{array}$ & Strategis \\
\hline 8 & $\begin{array}{l}\text { Keandalan } \\
\text { Produk }\end{array}$ & $\begin{array}{c}6,1 \\
4\end{array}$ & $\begin{array}{l}\text { Dapat } \\
\text { Diandalkan }\end{array}$ & $\begin{array}{c}6,2 \\
3\end{array}$ & $\begin{array}{l}\text { Sangat Dapat } \\
\text { Diandalkan }\end{array}$ \\
\hline 9 & $\begin{array}{l}\text { Tingkat Ramah } \\
\text { Lingkungan } \\
\text { Produk }\end{array}$ & $\begin{array}{c}6,4 \\
5\end{array}$ & $\begin{array}{l}\text { Sangat Ramah } \\
\text { Lingkungan }\end{array}$ & $\begin{array}{c}6,5 \\
9\end{array}$ & $\begin{array}{l}\text { Sangat Ramah } \\
\text { Lingkungan }\end{array}$ \\
\hline 10 & $\begin{array}{l}\text { Tingkat Ramah } \\
\text { Lingkungan } \\
\text { Proses } \\
\text { Tingkat Ramah }\end{array}$ & $\begin{array}{c}6,3 \\
6\end{array}$ & $\begin{array}{l}\text { Sangat Ramah } \\
\text { Lingkungan }\end{array}$ & $\begin{array}{c}5,9 \\
5\end{array}$ & $\begin{array}{l}\text { Ramah } \\
\text { Lingkungan }\end{array}$ \\
\hline 11 & $\begin{array}{l}\text { Lingkungan } \\
\text { dalam } \\
\text { Penggunaan } \\
\text { Produk }\end{array}$ & $\begin{array}{c}6,5 \\
5\end{array}$ & $\begin{array}{l}\text { Sangat Ramah } \\
\text { Lingkungan }\end{array}$ & $\begin{array}{c}6,4 \\
1\end{array}$ & $\begin{array}{l}\text { Sangat Ramah } \\
\text { Lingkungan }\end{array}$ \\
\hline 12 & $\begin{array}{l}\text { Tingkat Ramah } \\
\text { Lingkungan } \\
\text { Manajemen } \\
\text { Akhir Produk }\end{array}$ & $\begin{array}{c}6,1 \\
8\end{array}$ & $\begin{array}{l}\text { Sangat Ramah } \\
\text { Lingkungan }\end{array}$ & $\begin{array}{c}6,2 \\
3\end{array}$ & $\begin{array}{l}\text { Sangat Ramah } \\
\text { Lingkungan }\end{array}$ \\
\hline
\end{tabular}

toko memainkan peran penting dalam perilaku loyalitas toko [11].Berikut 15 pasangan faktor atribut yang digunakan.Penilaian factor atribut took non limbah dapat dilihat pada Tabel 3 .

\section{ANALISIS DAN DISKUSI}

\section{A. Analisis Semantic Differential}

Analisis semantic differential digunakan untuk membandingkan faktor atribut yang dimiliki tiap toko nol limbah. Berdasarkan uji reliabilitas, hasil reliabilitas faktor atribut yang digunakan menunjukkan nilai cronbach's alpha sebesar 0,924 pada faktor atribut Alang-Alang Zero Waste Store dan sebesar 0,936 pada Mamaramah Eco Bulk Store. Sehingga nilai cronbach's alpha yang dihasilkan dari faktor atribut pada kedua toko ini di atas batas yang ditetapkan yakni
Tabel 3.

Penilaian Faktor Atribut Toko Nol Limbah (Lanjutan)

\begin{tabular}{|c|c|c|c|c|c|}
\hline No & Faktor Atribut & $\mathrm{A}$ & Kategori & $\mathrm{M}$ & Kategori \\
\hline 13 & Sumber Bahan Baku & 6,18 & $\begin{array}{l}\text { Keseluruhan } \\
\text { Bahan Baku } \\
\text { dari } \\
\text { Produsen } \\
\text { Lokal }\end{array}$ & 5,73 & $\begin{array}{l}\text { Sebagian } \\
\text { Bahan } \\
\text { Baku } \\
\text { dari } \\
\text { Produsen } \\
\text { Lokal }\end{array}$ \\
\hline 14 & $\begin{array}{l}\text { Tingkat } \\
\text { Fungsionalitas } \\
\text { Produk }\end{array}$ & 6,45 & $\begin{array}{l}\text { Sangat } \\
\text { Tinggi }\end{array}$ & 6,18 & $\begin{array}{l}\text { Sangat } \\
\text { Tinggi }\end{array}$ \\
\hline 15 & $\begin{array}{l}\text { Tingkat Keamanan } \\
\text { Produk bagi } \\
\text { Kesehatan }\end{array}$ & 6,05 & Aman & 5,95 & Aman \\
\hline
\end{tabular}

*A = Alang-Alang Zero Waste Store; $M=$ Mamaramah Eco Bulk Store

0,7. Sehingga, keseluruhan faktor atribut yang digunakan pada penelitian ini dinyatakan layak dan dapat diandalkan.

Sebelum melakukan perbandingan nilai faktor atribut toko dari tiap toko, dilakukan penentuan rentang skala penilaian terlebih dahulu. Penelitian ini menggunakan perhitungan skala interval agar diperoleh pengetahuan terkait kategori sikap konsumen dan menginterpretasikan hasil nilai pelanggan yang didapatkan. Setelah itu dilakukan pengkategorian nilai ratarata tiap faktor atribut ke dalam rentang skala penilaian. Berikut contoh pengkategorian nilai faktor atribut dalam rentang skala penilaian.

Setelah sistem pengukuran pada setiap faktor atribut didefinisikan, maka analisis skala pengukuran semantic differential tersebut dapat memberikan hasil terkait sikap pelanggan terhadap kedua toko nol limbah. Berikut hasil perbandingan mean tiap faktor atribut yang dimiliki oleh tiap toko nol limbah yang dihasilkan dari penilaian pelanggan.

Berdasarkan hasil data di atas, berikut penjelasan mengenai kondisi terkini dari masing-masing toko nol limbah.

\section{1) Kesesuaian Harga dengan Kualitas}

Harga memberikan sensitivitas yang berbeda bagi tiap pelanggan toko. Dari faktor atribut kesesuaian harga dengan kualitas dapat dilihat bahwa baik Alang-Alang Zero Waste Store maupun Mamaramah Eco Bulk Store mampu menyediakan produk dengan harga yang sesuai dengan kualitas bagi pelanggannya. Namun jika dilihat dari segi nilai, nilai yang diperoleh Alang-Alang Zero Waste Store ini lebih tinggi dibandingkan Mamaramah Eco Bulk Store yang hanya memiliki nilai sebesar 5,68.

\section{2) Tingkat Kenyamanan Berbelanja}

Dari hasil penilaian faktor atribut berdasarkan penilaian pelanggan, dapat dilihat bahwa baik Alang-Alang Zero Waste Store maupun Mamaramah Eco Bulk Store memiliki atribut tingkat kenyamanan berbelanja yang masuk ke dalam kategori nyaman. Nilai faktor atribut Mamaramah Eco Bulk Store lebih tinggi yakni sebesar 6,14 dibandingkan Alang-Alang Zero Waste Store yang bernilai 6,05. Sehingga apabila melihat dari segi nilai, Mamaramah Eco Bulk Store mampu memberikan tingkat kenyamanan yang lebih tinggi bagi para pelanggan dibandingkan yang Alang-Alang Zero Waste Store lakukan. 


\section{3) Tingkat Keberagaman Produk}

Dalam hal tingkat keberagaman produk, para pelanggan kedua toko ini memberikan penilaian pada Mamaramah Eco Bulk Store yang lebih tinggi, yakni sebesar 6,14 dan Alang Alang Zero Waste Store sebesar 6,00. Alang-Alang Zero Waste Store menawarkan berbagai lini produk mulai dari bahan pangan, bumbu dapur, peralatan rumah tangga, produk makanan olahan organik hingga produk beauty and care. Sementara itu Mamaramah Eco Bulk Store juga memberikan berbagai macam penawaran lini produk, mulai dari cleaning product hingga nuts seeds beans. Dari hasil analisis yang telah dilakukan, dapat dilihat bahwa Mamaramah Eco Bulk Store memiliki lini produk yang lebih banyak sehingga ragam produk yang ditawarkan kepada konsumen semakin bervariasi. Sehingga dari segi nilai, ragam produk di Mamaramah Eco Bulk Store lebih variatif dibandingkan ragam produk yang disediakan Alang-Alang Zero Waste Store.

4) Kualitas Pelayanan

Dari segi faktor atribut kualitas pelayanan, Alang Alang Zero Waste Store mendapatkan nilai sebesar 5,91 dari para pelanggan sedangkan Mamaramah Eco Bulk Store mendapatkan nilai yang jauh lebih tinggi yakni sebesar 6,27 dari para pelanggan toko. Kualitas pelayanan pramuniaga toko menjadi salah satu komponen penyusun faktor kualitas pelayanan. Nilai Alang-Alang Zero Waste Store yang lebih rendah disebabkan karena kualitas pelayanan pramuniaga yang tidak lebih baik dari Mamaramah Eco Bulk Store berikan. Beberapa responden juga mengakui bahwa pelayanan yang diberikan pramuniaga toko di Mamaramah Eco Bulk Store lebih ramah dan lebih komunikatif dibandingkan yang pelanggan dapatkan di Alang-Alang Zero Waste Store. Dari nilai faktor kualitas pelayanan, dapat disimpulkan bahwa kualitas pelayanan Alang-Alang Zero Waste Store termasuk kategori memuaskan sedangkan Mamaramah Eco Bulk Store lebih unggul pada dimensi ini karena termasuk pada kategori pemberian kualitas pelayanan yang sangat memuaskan.

\section{5) Kualitas Fasilitas Fisik}

Pada dimensi atribut kualitas fasilitas fisik, nilai yang didapatkan Alang-Alang Zero Waste Store adalah sebesar 6,14 di mana nilai ini termasuk ke dalam kategori memadai. Namun, nilai yang didapatkan ini masih lebih rendah dibandingkan dengan nilai atribut kualitas fasilitas fisik di Mamaramah Eco Bulk Store sebesar 6,18 yang sudah termasuk ke dalam kategori sangat memadai. Sehingga dapat disimpulkan bahwa Mamaramah Eco Bulk Store memiliki kualitas fasilitas fisik yang lebih memadai.

\section{6) Keadaan atau Atmosfer Toko}

Keadaan atau atmosfer toko yang disuguhkan oleh pihak Alang-Alang Zero Waste Store mendapatkan nilai sebesar 5,77 dari para pelanggan. Hal ini menunjukkan bahwa Alang-Alang Zero Waste Store mampu menciptakan suatu atmosfer di toko yang menyenangkan bagi para pelanggan mereka yang berkunjung. Namun, hasil Alang- Alang Zero Waste Store ini masih sangat jauh dibandingkan dengan hasil penilaian yang diberikan pelanggan terhadap atribut atmosfer toko di Mamaramah Eco Bulk Store yang sebesar 6,50. Dapat dilihat bahwa pihak Mamaramah Eco Bulk Store lebih unggul dalam penciptaan suatu keadaan atau atmosfer toko yang sangat menyenangkan bagi para pelanggan mereka yang berkunjung.

\section{7) Lokasi Toko}

Pada aspek lokasi toko, Alang-Alang Zero Waste Store memperoleh nilai sebesar 5,36. Sehingga dapat dilihat bahwa lokasi toko Alang-Alang Zero Waste Store dinilai strategis bagi para pelanggan. Apalagi lokasi toko Alang-Alang Zero Waste Store yang juga setiap hari dilewati salah satu layanan bus dalam kota yang disediakan oleh Pemerintah Kota Surabaya, yakni Suroboyo Bus. Akan tetapi, nilai yang diperoleh Alang-Alang Zero Waste Store ini masih rendah dibandingkan nilai atribut lokasi toko Mamaramah Eco Bulk Store, yakni sebesar 5,55.

8) Keandalan Produk

Pada faktor atribut keandalan produk, Alang-Alang Zero Waste Store memiliki nilai sebesar 6,14 dan termasuk ke dalam kategori produk yang dapat diandalkan oleh para pelanggan mereka. Akan tetapi, nilai yang diperoleh AlangAlang Zero Waste Store masih lebih rendah dibandingkan penilaian keandalan produk Mamaramah Eco Bulk Store yang sebesar 6,23. Hal ini karena pada Mamaramah Eco Bulk Store produk mereka sangat dapat diandalkan oleh para pelanggan.

\section{9) Tingkat Ramah Lingkungan Produk}

Sebagai toko yang membawa konsep nol limbah, nilai ramah lingkungan adalah nilai utama yang menjadi pembeda toko nol limbah dengan toko reguler. Pada atribut tingkat ramah lingkungan produk, baik toko Alang-Alang Zero Waste Store maupun Mamaramah Eco Bulk Store memiliki produk yang sangat ramah dengan lingkungan. Hal ini menunjukkan bahwa kedua toko telah berhasil memenuhi tingkat ramah lingkungan produk yang ditawarkan dan sudah seharusnya hadir di sebuah toko nol limbah. Apabila dilihat dari nilai yang diperoleh, Mamaramah Eco Bulk Store mendapatkan nilai 6,59 yang mengungguli Alang-Alang Zero Waste Store yang memiliki nilai tingkat ramah lingkungan produk sebesar 6,45.

10) Tingkat Ramah Lingkungan Proses

Aspek ramah lingkungan lain yang terdapat pada toko nol limbah adalah di segi proses. Dari atribut tingkat ramah lingkungan proses, pelanggan memberikan nilai kepada AlangAlang Zero Waste Store sebesar 6,36. Sehingga dapat disimpulkan bahwa Alang-Alang Zero Waste Store mampu menghadirkan proses yang sangat ramah terhadap lingkungan. Pada atribut ini, Alang-Alang Zero Waste Store berhasil jauh mengungguli Mamaramah Eco Bulk Store yang hanya mendapatkan nilai 5,95 dari para pelanggan yang termasuk kategori proses yang ramah terhadap lingkungan.

11) Tingkat Ramah Lingkungan dalam Penggunaan Produk

Pada dimensi ini, baik Alang-Alang Zero Waste Store maupun Mamaramah Eco Bulk Store memiliki kesamaan yakni memiliki tingkat penggunaan produk yang sangat ramah terhadap lingkungan. Pelanggan memberikan nilai pada AlangAlang Zero Waste Store sebesar 6,55 sedangkan pada Mamaramah Eco Bulk Store sebesar 6,41. Sehingga dapat dilihat bahwa dari segi nilai, Alang-Alang Zero Waste Store 
memiliki nilai yang lebih tinggi dibandingkan Mamaramah Eco Bulk Store pada kategori atribut ini.

\section{2) Tingkat Ramah Lingkungan Manajemen Akhir Produk}

Pada dimensi ini, pelanggan memberikan nilai sebesar 6,18 pada Alang-Alang Zero Waste Store dan 6,23 pada Mamaramah Eco Bulk Store. Dari sisi kategori, kedua toko nol limbah yang menjadi objek pengamatan memiliki tingkat manajemen akhir produk yang sangat ramah lingkungan. Akan tetapi jika dilihat dari sisi nilai, Mamaramah Eco Bulk Store memiliki skor yang lebih tinggi dibandingkan Alang-Alang Zero Waste Store dari para pelanggan toko.

\section{3) Sumber Bahan Baku}

Atribut ini mampu mewakili nilai sosial yang dibawa oleh toko karena pemberdayaan petani lokal yang dilakukan. Nilai sosial juga mampu memengaruhi loyalitas dan niat beli pelanggan Alang-Alang Zero Waste Store. Hal ini karena berdasarkan temuan bahwa selain bersedia membayar ekstra untuk merek yang bertanggung jawab terhadap lingkungan, pelanggan juga cenderung membeli produk dari merek yang bertanggung jawab secara sosial, karena 70 persen menunjukkan bahwa mereka akan lebih cenderung membeli dari merek jika menangani masalah sosial dengan baik [12].

Penilaian yang diberikan pelanggan menunjukkan bahwa Alang-Alang Zero Waste Store termasuk kategori toko yang menggunakan bahan baku dari produsen lokal secara keseluruhan. Hal ini dapat dilihat dari nilai yang diperoleh yakni sebesar 6,18. Mamaramah Eco Bulk Store masih tertinggal jauh dibandingkan dengan Alang-Alang Zero Waste Store karena hanya memperoleh nilai sebesar 5,73 dari pelanggan. Nilai lebih tinggi yang diperoleh Alang-Alang Zero Waste Store pada atribut sumber bahan baku juga diperoleh karena sistem pengambilan sumber bahan baku dan produk dari petani lokal serta kegiatan pemasaran yang dilakukan secara berkelanjutan. Alang-Alang Zero Waste Store mengeklaim mereka menggunakan produk lokal sebesar 90 persen dari keseluruhan produknya. Selain itu, kegiatan pemasaran yang dilakukan toko adalah melakukan upload setiap hari Selasa yang menginformasikan pembukaan PreOrder (PO) fresh organic fruits and vegetables yang akan tersedia pada setiap hari Sabtu, di mana keseluruhan produknya dijual berdasarkan hasil dari panen petani lokal. Kegiatan pemasaran ini berguna untuk memberikan informasi dan membuat suatu reminder kepada konsumen bahwa produk dari toko bersumber dari produsen dan sumber daya lokal.

\section{4) Tingkat Fungsionalitas Produk}

Pada tingkat fungsionalitas produk, Alang-Alang Zero Waste Store jauh lebih unggul dibandingkan Mamaramah Eco Bulk Store berdasarkan penilaian yang diberikan oleh para pelanggan. Hal ini dapat dilihat dari nilai yang diperoleh Alang-Alang Zero Waste Store sebesar 6,45 sedangkan Mamaramah Eco Bulk Store memperoleh skor sebanyak 6,18.

\section{5) Tingkat Keamanan Produk bagi Kesehatan}

Faktor atribut produk terakhir yang digunakan adalah tingkat keamanan produk bagi kesehatan. Pada atribut ini Alang-Alang Zero Waste Store memperoleh nilai akhir sebesar 6,05 dari para pelanggan. Dapat disimpulkan bahwa dari segi nilai Alang-Alang Zero Waste Store cukup jauh lebih unggul dibandingkan Mamaramah Eco Bulk Store yang mendapatkan nilai sebesar 5,95 dari para pelanggan. Akan tetapi jika dilihat dari segi kategori, baik Alang-Alang Zero Waste Store maupun Mamaramah Eco Bulk Store telah berhasil memberikan produk yang aman bagi kesehatan pelanggan.

\section{B. Implikasi Manajerial}

Terdapat beberapa atribut yang harus ditingkatkan oleh Alang-Alang Zero Waste Store. Pihak toko dapat membuat pelanggan nyaman dengan pramuniaga toko melalui penyambutan yang ramah kepada pelanggan ketika mereka memasuki toko. Selain itu, pramuniaga toko dapat membangun kepercayaan dan hubungan yang baik dengan pelanggan, yakni dengan mengenal pelanggan seperti produk kegemaran atau produk yang sering mereka beli serta memahami kebutuhan pelanggan. Pihak Alang-Alang Zero Waste Store juga dapat menambah keberagaman produk toko dengan menambah lini produk yang dijual sehingga pelanggan mampu mendapatkan berbagai pilihan produk di toko secara sekaligus. Hal ini dapat dicapai dengan menciptakan kotak saran khusus untuk permintaan variasi produk, sehingga toko mampu menambahkan ragam produk sesuai request dan kebutuhan pelanggan.

Alang-Alang Zero Waste Store juga perlu meningkatkan kualitas pelayanan yang diberikan oleh pramuniaga dengan perubahan sikap pramuniaga yang lebih ramah, lebih sigap terkait kebutuhan pelanggan yang dapat dipenuhi toko, dan bersikap lebih infomatif terkait produk dan tahap pembelian yang harus dilakukan pelanggan. Kemudian, atribut selanjutnya yang perlu ditingkatkan Alang-Alang Zero Waste Store adalah atribut kualitas fasilitas fisik toko. Fasilitas fisik merupakan komponen krusial pada pengalaman in-store pelanggan karena atribut ini memfasilitasi kegiatan pembelian pelanggan di toko secara langsung maupun tidak langsung. Beberapa fasilitas fisik yang perlu ditambahkan Alang-Alang Zero Waste Store adalah penambakan pilihan metode pembayaran seperti credit atau debit card payment dan online payment seperti internet dan mobile banking (OVO, GoPay, LinkAja, mBCA, klikBCA, dan lain-lain), bagi pelanggan yang ingin menyelesaikan pembayaran dengan cepat dan efisien. Selain itu, Alang-Alang Zero Waste Store perlu menata produk dengan lebih rapi dan dilakukan pelabelan dengan product grouping sehingga produk dipajang berdasarkan kategori lini produk.

\section{SIMPULAN DAN SARAN}

\section{A. Simpulan}

Dari hasil analisis faktor atribut melalui analisis skala semantic differential yang didasarkan pada penilaian pelanggan, Mamaramah Eco Bulk Store berhasil mengungguli Alang-Alang Zero Waste Store pada 9 faktor atribut, yakni 6 atribut toko dan 3 atribut produk. Atribut toko dan produk tersebut adalah tingkat kenyamanan berbelanja, tingkat keberagaman produk, kualitas pelayanan, kualitas fasilitas 
fisik, keadaan atau atmosfer toko, lokasi toko, keandalan produk, tingkat ramah lingkungan produk, dan tingkat ramah lingkungan manajemen akhir produk.

\section{B. Saran}

Penelitian selanjutnya dapat dilaksanakan di skala wilayah yang lebih luas sehingga hasil analisis dapat bersifat lebih umum. Selain itu, penelitian selanjutnya juga dapat melakukan uji validitas faktor secara konstruk dengan alat statistik untuk mengonfirmasi faktor yang digunakan memiliki tingkat akurasi yang tinggi dalam melihat perbandingan penilaian pelanggan.

\section{DAFTAR PUSTAKA}

[1] T. Curran and I. D. Williams, "A zero waste vision for industrial networks in Europe," J. Hazard. Mater., vol. 207, pp. 3-7, 2012.

[2] G. Farraj, "Consumer-Goods' Brands That Demonstrate Commitment to Sustainability Outperform Those That Don't," 2015.
[3] Nielsen Media Research, "Nielsen Global Corporate Sustainability Report," New York, 2015.

[4] Nielsen Media Research, "Sustainability Continues to Gain Momentum Among Malaysian Consumers," 2015.

[5] A. Sharma, "Greenwashing: A Study on the Effects of Greenwashing on Consumer Perception and Trust Build-Up," no. January, 2019.

[6] Mamaramah Eco Bulk Store, "About Us," 2019. .

[7] P. Hartmann and V. Apaolaza Ibáñez, "Green value added," Mark. Intell. Plan., vol. 24, no. 7, pp. 673-680, 2006, doi: 10.1108/02634500610711842.

[8] The Huffington Post, "What Are You Wasting For? This Is The Year 'Zero Waste' Becomes A Movement," Feb. 2019.

[9] N. K. Malhotra, Marketing Research. New Jersey: Pearson Education, 2009.

[10] Sugiyono, Metode Penelitian Pendidikan: Pendekatan Kuantitatif, Kualitatif dan R\&D. Bandung: Alfabeta, 2006.

[11] $\mathrm{H}$. Hu and C. R. Jasper, "Social cues in the store environment and their impact on store image," Int. J. Retail Distrib. Manag., vol. 34, no. 1, pp. 25-48, 2006.

[12] Nielsen Media Research, "Millenials on Millenials: Shopping Insights in A New Era," 2018. 